\title{
PROBLEMATIKA PENJATUHAN HUKUMAN PIDANA MATI DALAM PERSPEKTIF HAK ASASI MANUSIA DAN HUKUM PIDANA
}

Oleh:

\author{
Amelia Arief \\ Sekolah Tinggi IImu Sosial \& IImu Politik (STISIP) 17-8-1945 Makassar \\ E-mail: ameliaa.ariefff@yahoo.co.id
}

\begin{abstract}
Abstrak
Tujuan dilakukan penelitian ini adalah untuk menganalisis tentang penjatuhan hukuman pidana mati dalam kaitannya dengan Hak Asasi Manusia dan hukum Pidana. Penelitian dilakukan dengan menggunakan penelitian hukum yuridis-normatif, Hasil penelitian menunjukkan, pertama, masalah hukuman mati, terdapat berbagai pandangan dari pemikiran para ahli hukum. Kedua, Hukuman mati dalam pandangan Hak Asasi Manusia yang ada dalam Undang-Undang Dasar Negara Republik Indonesia, dan Undang-undang Nomor 39 Tahun 1999 tentang Hak Asasi Manusia berusaha mengadopsi piagam Hak Asasi Manusia Perserikatan Bangsa-Bangsa untuk menghapuskan hukuman mati. Ketiga, dalam Kitab Undang-undang Hukum Pidana dan beberapa peraturan perundangundangan di Indonesia, ancaman pidana mati masih tetap dipertahankan, walaupun mendapat kritikan dari para aktifis Hak Asasi Manusia, karena itu dalam Rancangan Kitab Undang-Undang Hukum Pidana yang baru ada semacam kompromi (penal policy), dengan menjadikan hukuman mati bukan sebagai pidana pokok tetapi sebagai pidana altematif yang diperlakukan hanya bagi kejahatan luar biasa.
\end{abstract}

Kata kunci: Hukuman Mati, Hak Asasi Manusia, Hukum Pidana

\section{A. PENDAHULUAN}

Penjatuhan pidana kepada pelaku tindak pidana merupakan kewenangan hakim dengan mempertimbangkan secara yuridis dan sosiologis agar pidana yang dijatuhkan dapat bermanfaat baik bagi terpidana maupun masyarakat. ${ }^{1}$ Oleh karena itu konsep penjeraan dimodifikasi dalam pelaksanaan putusan pidana penjara dengan konsep pembinaan. Untuk itu penerapan pidana harus memperhatikan tujuan pemidanaan (straf soort), berat ringan pidana (straf), dan cara penjatuhan pidana (straf modus).

Konstitusi Republik Indonesia Undang-Undang Dasar 1945 menjamin Hak Asasi Manusia sebagaimana diatur dalam Pasal 28A-28J. Dalam konstitusi tersebut dijelaskan bahwa Hak Asasi Manusia sangat dijunjung tinggi bagi setiap

Warih Anjari, 2015, Penjatuhan Pidana Mati di Indonesia dalam Perspektif Hak Asasi Manusia, Jurnal Widya Yustisia, 1(2), hlm.108. 
orang baik. Adapun pengaturan lebih lanjut terkait Hak Asasi Manusia akan diatur dalam perundang-undangan yang ada. ${ }^{2}$ Semantara dalam Kitab Undang-Undang Hukum Pidana (KUHP) Indonesia, stelsel pidana diatur dalam Pasal $10 \mathrm{KUHP}$, yang menyebutkan ada 2 jenis pidana yaitu: (1) Pidana Pokok, yang terdiri dari: (a) pidana mati, (b) pidana penjara, (c) pidana kurungan, dan (d) pidana denda; (2) Pidana Tambahan, yang terdiri dari: (a) pencabutan hak tertentu, (b) perampasan barang tertentu, (c) pengumuman putusan hakim; (3) Pidana Tutupan, dengan dasar Undang-Undang Nomor 20 Tahun 1946 tentang Pidana Tutupan.

Pidana mati berstatus sebagai pidana pokok, merupakan jenis pidana yang mengandung pro dan kontra. Pada tingkat internasional pidana jenis ini dilarang untuk dijatuhkan kepada terpidana. Perserikatan Bangsa-Bangsa (PBB) mendorong untuk ditiadakannya penerapan jenis pidana ini berdasarkan Deklarasi Hak-Hak Asasi Manusia (Universal Declaration of Human Rights) yang diadopsi pada tanggal 10 Desember 1948, dengan menjamin hak hidup dan perlindungan terhadap penyiksaan. Demikian pula dijaminnya hak untuk hidup terdapat dalam Pasal 6 International Convenant on Civil and Political Rights/ ICCPR) yang diadopsi tahun 1966 dan diratifikasi dengan Undang-Undang Nomor 12 Tahun 2005 tentang Pengesahan ICCPR. ${ }^{3}$ Sistem hukum pidana Indonesia berusaha melepaskan pidana mati di luar pidana pokok, dengan mengaturaya sebagai pidana alternatif Pidana mati tidak lagi merupakan pidana pokok pertama, tetapi menjadi pidana yang bersifat khusus.

Menghormati tentang pidana mati (hukuman mati) di Indonesia sebagai suatu negara yang mempunyai falsafah Pancasila sampai saat sekarang ini adalah merupakan suatu pembicaraan yang dapat menimbulkan problematika (antara yang pro dan yang kontra), karena masih banyak diantara para ahli hukum yang mempersoalkannya hal ini disebabkan antara lain karena adanya perbedaan dan tinjauan. ${ }^{4}$ Bagi kalangan yang menolak pidana mati, hukuman mati dianggap

2 Laras Astuti, 2016, Penegakan Hukum Pidana Indonesia dalam Penyelesaian Pelanggaran Hak Asasi Manusia, Jurnal Kosmik Hukum, 16(2), hIm. 108.

3 Eva Achjani Zulfa, 2007, Menakar Kembali Keberadaan Pidana Mati (Suatu Pergeseran Paradigma Pemidanaan Di Indonesia), Lex Jurnalica, 4(2), hlm. 94.

4 Atet Sumanto, 2004, Kontradiksi Hukuman Mati di Indonesia Dipandang dari Aspek Hak Asasi Manusia. Agama dan Para Ahli Hukum, Perspektif, 9(3), hlm. 197. 
bertentangan dengan Hak Asasi Manusia (HAM). ${ }^{5}$ Perjuangan mereka misalnya terlihat pada perubahan status pidana mati yang tercantum dalam draft Konsep KUHP baru, yang akan diajukan untuk ditetapkan oleh Dewan Perwakilan Rakyat. Pasal 66 Rancangan KUHP menyatakan bahwa pidana mati menjadi pidana pokok yang bersifat khusus dan diancamkan alternatif dengan pidana pokok lainnya. Pelaksanaan pidana ini dengan cara menembak terpidana sampai mati dan tidak dilaksanakan di muka umum. Penjatuhan pidana mati dianggap mengambil hak hidup seseorang. Padahal setiap orang berhak untuk hidup dan berhak mempertahankan hidup dan kehidupannya (Pasal 28A UUD 1945). Kalangan penolak pidana mati menganggap pidana mati tidak selaras lagi dengan perkembangan HAM. Semua negara memiliki konsep menjunjung tinggi HAM, dan Indonesia sebagai bagian dari negara di dunia harus ikut serta dalam mewujudkan HAM. $^{6}$ Menurut mereka diaturnya HAM secara legal formal dalam negara RI seharusnya Indonesia telah meninggalkan hukuman mati. HAM terutama hak hidup dinyatakan sebagai hak yang tidak dapat dikurangi dalam bentuk apapun (non derogable rights). Hal ini disebutkan dalam Pasal 28 I ayat (1) dan Pasal 28J ayat (2) UUD 1945, Pasal 4 Undang-Undang Nomor 39 Tahun 1999 tentang HAM.

Namun secara positif, penerapan pidana mati masih banyak diputus oleh hakim. Sebagai contoh kasus terbunuhnya Sisca Yofie yang pelakunya adalah Wawan dipidana oleh Mahkamah Agung melalui putusannya pada tanggal 11 November 2014 dari pidana seumur hidup menjadi pidana mati. Pertimbangannya adalah perbuatan yang dilakukan terdakwa terhadap korban dengan cara yang sadis dan untuk memberikan efek jera serta agar masyarakat menghargai hak hidup orang lain. (www.tempo.com). Jaksa Agung akan melaksanakan eksekusi mati terhadap 5 orang terpidana mati pada tahun 2014, dan 20 orang pada tahun 2015 (www.hukumonline.com). Presiden Jokowi menolak permohonan grasi yang diajukan 64 terpidana mati perkara narkoba (Kompas, Rabu, 10 Desember 2014: 3). Terkhir dengan pidana mati dilakukan terhadap gembong narkoba Fredy Budiman.

5 M. Abdul Kholiq, 2007, Kontroversi Hukuman Mati dan Kebijakan Regulasinya dalam RUU KUHP (Studi Komparatif Menurut Hukum Islam), Jurnal Hukum, 14(2), hlm. 186.

6 Satrio Putra Kolopita, 2013, Penegakan Hukum Atas Pidana Mati Terhadap Pelaku Tindak Pidana Narkotika, Lex Crimen, 4(2), hlm. 67. 


\section{B. METODE PENELITIAN}

Metode penelitian yang digunakan dalam mengkaji penelitian ini adalah metode penelitian yuridis-normatif. Pendekatan yuridis adalah suatu pendekatan yang mengacu pada pada hukum dan peraturan perundang-undangan yang berlaku, teori hukum dan pendapat ahli. Sedangkan pendekatan normatif adalah pendekatan yang dilakukan dengan cara meneliti bahan pustaka sekunder.

\section{PEMBAHASAN}

\section{Hukuman Mati dalam Perspektif Hak Asasi Manusia (HAM)}

Secara historis, kemunculan Hak Asasi Manusia (HAM) adalah proses pembelaan kepada masyarakat atas tindakan sewenang-wenangan yang dilakukan oleh negara dan juga karena tidak seimbangnya posisi negara dengan masyarakat. ${ }^{7}$ Dalam perspektif Universal Declaration Of Human Rights, deklarasi umum tentang hak asasi manusia (DUHAM) hukuman mati dilarang. ${ }^{8} \mathrm{Hal}$ ini sesuai dengan ketentuan pada Pasal 3 Deklarasi Universal yang berbunyi: "every human being has the right to life. This right shall be protected by law. No one shall be arbitrarily deprived of his life". (Setiap orang mempunyai hak atas penghidupan, kemerdekaan dan keselamatan seseorang). Ketentuan dalam DUHAM ini kemudian dipertegas dalam kovenan di bidang hak-hak sipil dan politik yaitu Pasal 6 ayat 1 dan Pasal 7 Kovenan Internasional tentang Hak Sipil dan Politik (International Covenant on Civil and Political Rights-ICCPR) sekaligus dikuatkan lagi oleh Protocol Opsional Kedua (Second Optional Protocol) atas Perjanjian Internasional Mengenai Hak-hak Sipil dan Politik Tahun 1989 tentang Penghapusan Hukuman Mati. Isi dari Pasal 6 Kovenan Internasional tentang Hak Sipil dan Politik dikutip lengkap sebagai berikut.

7 Syamsul Haling, et.all., 2018, Perlindungan Hak Asasi Anak Jalanan dalam Bidang Pendidikan Menurut Hukum Nasional dan Konvensi Internasional, Jurnal Hukum \& Pembangunan, 48(2), hlm. 365.

8 Saharuddin Daming, 2016, Konfigurasi Pertarungan Abolisionisme Versus Retensionisme dalam Diskursus Keberadaan Lembaga Pidana Mati di Tingkat Global dan Nasional, Yustisi, 3(1), hlm. 40. 
(1) Setiap manusia berhak atas hak untuk hidup yang melekat pada dirinya. Hak ini wajib dilindungi oleh hukum. Tidak seorang pun dapat dirampas hak hidupnya secara sewenang-wenang.

(2) Di negara-negara yang belum menghapuskan hukuman mati, putusan hukuman mati hanya dapat dijatuhkan terhadap beberapa kejahatan yang paling serius sesuai dengan hukum yang berlaku pada saat dilakukannya kejahatan tersebut, dan tidak bertentangan dengan ketentuan Kovenan dan Konvensi tentang Pencegahan dan Hukum Kejahatan Genosida. Hukuman ini hanya dapat dilaksanakan atas dasar keputusan akhir yang dijatuhkan oleh suatu pengadilan yang berwenang.

(3) Apabila suatu perampasan kehidupan merupakan kejahatan Genosida, harus dipahami, bahwa tidak satu pun dalam Pasal ini yang memberikan kewenangan pada Negara yang menjadi Pihak dalam Kovenan ini, untuk mengurangi kewajiban apapun yang telah dibebankan oleh ketentuan dalam Konvensi tentang Pencegahan dan Hukuman bagi Kejahatan Genosida.

(4) Setiap orang yang telah dijatuhi hukum mati berhak untuk memohon pengampunan atau penggantian hukuman. Amnesti, pengampunan atau penggantian hukuman mati dapat diberikan dalam semua kasus.

(5) Hukuman mati tidak boleh dijatuhkan atas kejahatan yang dilakukan oleh seseorang di bawah usia delapan belas tahun dan tidak boleh dilaksanakan terhadap perempuan yang tengah mengandung.

(6) Tidak ada satu pun dalam Pasal ini yang boleh dipakai untuk menunda atau mencegah penghapusan hukuman mati oleh Negara yang menjadi Pihak dalam Kovenan ini.

Sedangkan dalam Pasal 7 Kovenan Internasional tentang Hak Sipil dan Politik menyatakan, Tidak seorang pun yang dapat dikenakan penyiksaan atau perlakuan atau hukuman lain yang keji, tidak manusiawi atau merendahkan martabat. Pada khususnya, tidak seorang pun dapat dijadikan obyek eksperimen medis atau ilmiah tanpa persetujuan yang diberikan secara bebas.

Pada beberapa instrument HAM, larangan hukuman mati dimuat dalam sebuah protokol tersendiri. Kovenan Internasional tentang Hak-hak Sipil dan 
Politik dan Konvensi Amerika, keduanya membatasi hukuman mati pada "kejahatan yang paling berat." Keduanya mengatur bahwa hukuman mati harus hanya boleh dikenakan oleh sesuatu "keputusan final suatu pengadilan yang berwenang" sesuai dengan undang-undang yang tidak retroaktif. ${ }^{9}$

Intisari dari hukuman mati dalam perspektif DUHAM adalah dilarang, Dalam pandangan HAM versi $\mathrm{PBB}$, penerapan hukuman mati digolongkan sebagai bentuk hukuman yang kejam/keji dan tidak manusiawi, melanggar Pasal 3 Deklarasi Universal Hak Asasi Manusia (Universal Declaration of Human Rights); dan Pasal 7 (International Covenant on Civil and Political Rights-ICCPR). Berdasarkan kovenan tersebut sekalipun asasnya dilarang tetapi jika ada negara-negara yang masih memperlakukan/belum menghapuskan hukuman mati hanya terbatas diperlakukan kepada kejahatan/atau tindak pidana tertentu (khusus/serius) seperti kejahatan genosida atau terorisme (Pasal 6 ayat 2 International Covenant on Civil and Political Rights-ICCPR).

Negara Indonesia akhir-akhir ini mulai mengadopsi pemikiran yang berkembang di dunia tentang HAM, dan mengadopsi DUHAM PBB masuk dalam konstitusi dan juga dalam Undang-Undang Nomor 39 Tahun 1999 tentang Hak Asasi Manusia, sekaligus pembentukan Komisi Nasional Hak Asasi Manusia (Komnas HAM). Pada Konstitusi Republik Indonesia setelah perubahan (amandemen) termaktub dalam Pasal 28A disebutkan: "Setiap orang berhak untuk hidup serta berhak mempertahankan hidup dan kehidupannya." Hak untuk hidup serta mempertahankan hidup dan kehidupan (Pasal 28A) mirip sekali dengan isi dari Pasal 3 DUHAM PBB.

Ketentuan dalam Pasal 28A UUD RI 1945 tersebut kemudian dirinci dalam Undang-Undang No. 39 Tahun 1999 tentang Hak Asasi Manusia. Pada Bab III: Hak Asasi Manusia dan Kebebasan Dasar Manusia; Bagian Kesatu: Hak untuk Hidup pada Pasal 9:

(1) setiap orang berhak untuk hidup, mempertahankan hidup dan meningkatkan taraf kehidupannya;

9 Habib Shulton Asnawi, 2012, Hak Asasi Manusia Islam dan Barat: Studi Kritik Hukum Pidana Islam dan Hukuman Mati, Supremasi Hukum,1(1), hlm. 26. 
(2) setiap orang berhak hidup tenteram, aman, damai, bahagia, sejahtera lahir dan batin;

(3) setiap orang berhak atas lingkungan hidup yang baik dan sehat.

Selanjutnya dalam Bab IV: Kewajiban Dasar Manusia; Pasal 67: Setiap orang yang ada di wilayah negara Republik Indonesia wajib patuh pada peraturan perundang-undangan, hukum tak tertulis, dan hukum internasionai mengenai hak asasi manusia yang telah diterima oleh negara Republik Indonesia. Pasal 69 Undang-Undang No. 39 Tahun 1999 tentang Hak Asasi Manusia menetapkan:

(1) setiap orang wajib menghormati hak asasi manusia orang lain, moral etika, dan tata tertib kehidupan bermasyarakat, berbangsa, dan bernegara;

(2) setiap hak asasi manusia seseorang menimbulkan kewajiban dasar dan tanggung jawab untuk menghormati hak asasi orang lain secara timbal balik serta menjadi tugas Pemerintah untuk menghormati, melindungi, menegakkan, dan memajukannya.

Selanjutnya pada Pasal 70 Undang-Undang No. 39 Tahun 1999 tentang Hak Asasi Manusia: Dalam menjalankan hak dan kewajiban, setiap orang wajib tunduk kepada pembatasan yang ditetapkan oleh Undang-undang dengan maksud untuk menjamin pengakuan serta penghormatan atas hak dan kebebasan orang lain dan untuk memenuhi tuntutan yang adil sesuai dengan pertimbangan moral, keamanan, dan ketertiban umum dalam suatu masyarakat demokratis. Pasal 73 Undang-Undang No. 39 Tahun 1999 tentang Hak Asasi Manusia menjelaskan bahwa hak dan kebebasan yang diatur dalam Undang-undang ini hanya dapat dibatasi oleh dan berdasarkan Undang-undang, semata-mata untuk menjamin pengakuan dan penghormatan terhadap hak asasi manusia serta kebebasan dasar orang lain, kesusilaan, ketertiban umum, dan kepentingan bangsa.

\section{Hukuman Mati dalam Perspektif Hukum Pidana Indonesia}

Secara umum pidana mati didefinisikan sebagai suatu nestapa atau penyiksaan yang memberikan penderitaan kepada manusia dan melanggar norma-norma yang bertentangan dengan kehidupan manusia, dimana antara pidana mati sangat berkaitan dengan pidana dan pemidanaan. Pidana dalam 
hal pemberian sanksi, sedangkan pemidanaan lebih dibebankan kepada si pelaku tindak pidana, dengan pemberian pidana mati diharapkan masyarakat dapat melihat bahwa pelakunya benar-benar ditindak. ${ }^{10}$ Dalam hukum pidana Indonesia terdapat beberapa kejahatan yang diancam dengan pidana mati, antara lain sebagai berikut.

a. Tindak pidana makar, diatur dalam Pasal 104 KUHP berupa membunuh presiden dan wakil presiden; Pasal 111 ayat (2) berupa melakukan hubungan dengan negara asing sehingga terjadi perang.

b. Tindak pidana pembunuhan berencana, diatur dalam Pasal 340 KUHP berupa menghilangkan nyawa orang lain dengan sengaja dan berencana.

c. Tindak pidana korupsi, diatur dalam Pasal 2 ayat (2) Undang-undang Nomor 31 Tahun 1999 jo. Nomor 20 Tahun 2001 tentang Pemberantasan Tindak Pidana Korupsi, berupa korupsi dalam keadaan tertentu.

d. Tindakan pidana genoside dan kejahatan terhadap manusia, diatur dalam Undang-undang Nomor 26 Tahun 2000 tentang Hak Asasi Manusia. Pasal 36 mengatur tentang genoside yaitu setiap perbuatan yang dilakukan untuk menghancurkan atau memusnahkan seluruh atau sebagian kelompok bangsa, ras kelompok etnis, kelompok agama, ${ }^{11}$ Pasal 37 tentang mengatur tentang kejahatan terhadap kemanusiaan yaitu perbuatan yang dilakukan sebagai bagian dari serangan yang meluas atau sistematik yang ditujukan secara langsung terhadap penduduk sipil.

e. Tindak pidana Narkotika, diatur dalam Pasal 114, 116, 118, 119, dan 121 Undang-undang Nomor 35 Tahun 2009 tentang Narkotika. Pada intinya pasal tersebut menyatakan menawar, menjual, membeli, menerima, menjadi perantara dalam jual beli, menukar, atau menyerahkan narkotika.

f. Tindak pidana melakukan Mobilisasi Anak dalam Perdagangan Gelap Narkotika, diatur dalam Pasal 89 Undang-undang Nomor 23 Tahun 2002 tentang Perlindungan Anak, yang menyatakan secara sengaja melibatkan anak dalam penyalahgunaan, produksi, atau distribusi narkotika dan/atau psikotropika.

10 Fransiska Novita Eleanora, 2012, Eksistensi Pidana Mati dalam Perspektif Hukum Pidana, Widya, 29 (318), hlm. 11.

11 Chairul Huda, 2011, Pola Pemberatan Pidana dalam Hukum Pidana Khusus, Jurnal Hukum, 18 (4), hlm. 521. 
Juga beberapa undang-undang yang masih berlaku di Indonesia ancamannya diancam dengan hukuman mati, seperti disajikan dalam label berikut ini.

Tabel 1. Ketentuan Mengenai Ancaman Hukuman Mati

\begin{tabular}{|c|c|c|}
\hline No & Peraturan & Ketentuan \\
\hline 1 & KUHP & $\begin{array}{l}\text { Pasal 104; Pasal } 111 \text { ayat (2); Pasal } \\
124 \text { ayat (3); Pasal 140; Pasal } 340 \text {; } \\
\text { Pasal } 365 \text { ayat (4); Pasal } 444 \text { Pasal } \\
1368 \text { ayat (2). }\end{array}$ \\
\hline 2 & $\begin{array}{l}\text { Kitab Undang-undang Hukum } \\
\text { Pidana Militer (KUHPM) }\end{array}$ & $\begin{array}{l}\text { Pasal } 64 \text {; Pasal } 65 \text {; Pasal } 67 \text {; Pasal } 68 \text {; } \\
\text { Pasal } 73 \text { ke } 1 \text {, ke } 2 \text {, ke } 3 \text { dan ke } 4 \text {; } \\
\text { Pasal } 74 \text { ke } 1 \text { dan ke } 2 \text {; Pasal } 76 \text { ayat } \\
\text { (1); Pasal } 82 \text {; Pasal } 89 \text { ke } 1 \text { dan ke } 2 \text {; } \\
\text { Pasal } 109 \text { ke } 1 \text { dan ke } 27 \text {; Pasal } 114 \\
\text { ayat (1); Pasal } 133 \text { ayat (1) dan (2); } \\
\text { Pasal } 135 \text { ayat (1) ke } 1 \text { dan ke } 2 \text {, ayat } \\
\text { (2); Pasal } 137 \text { ayat (1) dan (2); Pasal } \\
138 \text { ayat (1) dan (2); dan Pasal } 142 \\
\text { ayat (2) }\end{array}$ \\
\hline 3 & $\begin{array}{l}\text { Undang-undang Nomor } \\
\text { 12/DH/1951 tentang Senjata } \\
\text { Api }\end{array}$ & Pasal 1 ayat $(1)$ \\
\hline 4 & $\begin{array}{l}\text { Penpres Nomor } 5 \text { Tahun } 1959 \\
\text { tentang Wewenang Jaksa } \\
\text { Agung/Jaksa Tentara Agung } \\
\text { dalam Hal Memperberat } \\
\text { Ancaman Hukuman terhadap } \\
\text { Tindak Pidana yang } \\
\text { Membahayakan Pelaksanaan } \\
\text { Perlengkapan Sandang } \\
\text { Pangan }\end{array}$ & Pasal 2 \\
\hline 5 & $\begin{array}{l}\text { Perppu Nomor } 21 \text { Tahun } 3959 \\
\text { tentang Memperberat } \\
\text { Ancaman Hukuman terhadap } \\
\text { Tindak Pidana Ekonomi }\end{array}$ & Pasal 1 ayat (1) dan ayat (2) \\
\hline 6 & $\begin{array}{l}\text { Undang-undang Nomor } \\
\text { 31/PNPS/1964 tentang } \\
\text { Ketentuan Pokok Tenaga } \\
\text { Atom }\end{array}$ & Pasal 23 \\
\hline 7 & $\begin{array}{l}\text { Undang-undang Nomor } 4 \\
\text { Tahun } 1976 \text { tentang } \\
\text { Perubahan dan Penambahan } \\
\text { Beberapa Pasal dalam KUHP } \\
\text { Bertalian dengan Perluasan } \\
\text { Berlakunya Ketentuan } \\
\text { Perundang-Undangan Pidana } \\
\text { Kejahatan Penerbangan dan }\end{array}$ & Pasal 479 huruf $k$ ayat $(2)$ \\
\hline
\end{tabular}




\begin{tabular}{|c|c|c|}
\hline & $\begin{array}{l}\text { Kejahatan terhadap Sarana/ } \\
\text { Prasarana Penerbangan }\end{array}$ & \\
\hline 8 & $\begin{array}{l}\text { Undang-undang Nomor } 5 \\
\text { Tahun } 1997 \text { tentang } \\
\text { Psikotropika }\end{array}$ & Pasal 59 ayat (2) \\
\hline 9 & $\begin{array}{l}\text { Undang-undang Nomor } 35 \\
\text { Tahun } 2009 \text { tentang Narkotika }\end{array}$ & $\begin{array}{l}\text { Pasal } 74 \text {; Pasal } 113 \text { ayat (2); Pasal } 114 \\
\text { ayat (2); Pasal } 119 \text { ayat (2); Pasal } 118 \\
\text { ayat (2); Pasal } 119 \text { ayat (2); Pasal } 121 \\
\text { ayat (2); Pasal } 132 \text { ayat (3); Pasal } 133 \\
\text { ayat (1); Pasal } 144 \text { ayat (2) }\end{array}$ \\
\hline 10 & $\begin{array}{l}\text { Undang-undang Nomor } 31 \\
\text { Tahun } 1999 \text { tentang } \\
\text { Pemberantasan Korupsi }\end{array}$ & Pasal 2 ayat $(2)$ \\
\hline 11 & $\begin{array}{l}\text { Undang-undang Nomor } 26 \\
\text { Tahun } 2000 \text { tentang } \\
\text { Pengadilan Hak Asasi } \\
\text { Manusia }\end{array}$ & $\begin{array}{l}\text { Pasal 36; Pasal 37; Pasal 41; Pasal } 42 \\
\text { ayat (3) }\end{array}$ \\
\hline 12 & $\begin{array}{l}\text { Undang-undang Nomor } 15 \\
\text { Tahun } 2003 \text { tentang } \\
\text { Pemberantasan Tindak } \\
\text { Pidana Terorisme }\end{array}$ & $\begin{array}{l}\text { Pasal 6; Pasal 8; Pasal 9; Pasal 10; } \\
\text { Pasal 14; Pasal 15; Pasal } 16\end{array}$ \\
\hline 13 & $\begin{array}{l}\text { Undang-undang Nomor } 35 \\
\text { Tahun } 2014 \text { tentang } \\
\text { Perubahan atas Undang- } \\
\text { undang Nomor } 23 \text { Tahun } \\
2002 \text { tentang Perlindungan } \\
\text { Anak }\end{array}$ & Pasal 89 ayat (1) \\
\hline
\end{tabular}

Penjatuhan pidana mati berdasarkan putusan pengadilan, pernah dijatuhkan dalam beberapa kasus, antara lain:

a. pembunuhan berencana di Sumatera Selatan tahun 1992 atas nama terpidana Suiyadi Swabhuana alias Adi Kumis alias Dodi bin Soekamo;

b. pembunuhan dan mutilasi di Sumatera Selatan tahun 1997 atas nama terpidana Jurit bin Abdullah;

c. pembunuhan dan mutilasi di Sumatera Selatan tahun 1997 atas nama Ibrahim bin Ujang;

d. penyelundupan 100 gram heroin atas nama Adami Wilson alias Adam alias Abu ditangkap 2003 dieksekusi 14 Maret 2014;

12 Supriyadi W. Eddyono dan Erasmus A.T. Napitupuhi, 2015, Hukuman Mati dalam R KUHP: Jalan Tengah yang Meragukan, Institute for Criminal Justice Reform, Jakarta, hlm. 10-11. 
e. membawa 1050 gram heroin atas nama terpidana Muhammad Abdul Hafeez ditangkap 2001 dieksekusi 17 November 2013 (Kompas, Jumat 14 November 2014:14);

f. pembunuhan disertai dengan sodomi terhadap anak-anak atas nama terpidana Baekuni yang diputus pada tanggal 21 April 2011;

g. pembunuhan berencana 11 orang dengan cara mutilasi atas nama terpidana Verry Idham Henyansyah yang diputus pada tanggal 5 Juli 2012;

h. pembunuhan sadis dan pemerkosa atas nama terpidana Herris Marbun yang divonis tanggal 8 Januari 2014;

i. pembunuhan istri dan 2 orang anaknya atas nama terpidana Herman Jumat Masan yang divonis pada tanggal 11 Pebruari 2014;

j. Pembunuhan berencana dan penganiayaan berat atas nama terpidana Slamet Riyanto yang divonis pada tanggal 17 September 2014;

k. pencurian dengan kekerasan yang berakibat hilangnya nyawa orang lain pada tanggal 5 Agustus 2013 atas nama terpidana Wawan. (Kompas, Kamis 13 November 2013:1).

Pada akhir tahun 2014 terdapat 148 orang narapidana yang divonis mati oleh pengadilan menunggu eksekusi. Kasus yang dilakukan oleh terpidana mati karena terbukti melakukan pembunuhan berencana dan bandar narkoba (Kompas, Jumat 14 November 2014: 4). Namun berbeda pada putusan pidana mati atas nama terpidana Wawan yang awalnya terbukti melakukan pencurian dengan kekerasan yang berakibat hilangnya nyawa orang lain. Pembunuhan ini dilakukan tanpa alasan yang kuat, tanpa empati, sadis dan tidak berperikemanusiaan. Dalam pertimbangannya Majelis Hakim Mahkamah Agung menyatakan terpidana terbukti secara sah dan meyakinkan melakukan pembunuhan berencana terhadap korban, pelaku menyeret korban sejauh 800 meter dalam keadaan masih hidup lalu mengeksekusi korban (Kompas, Sabtu 15 November 2014: 2). Pidana mati yang dijatuhkan oleh Mahkamah Agung dengan alasan membela hak asasi, disertai dengan kekerasan dan penganiayaan terhadap korban. Hal ini tercantum dalam Pasal 28 J UUD 1945 yang menyatakan setiap orang wajib menghormati hak asasi orang lain dan wajib tunduk pada pembatasan yang ditetapkan undang-undang untuk menjamin pengakuan serta pengliormatan hak dan kebebasan orang lain 
Sedangkan sistem hukum pidana Indonesia masih menganut hukuman mati yang diperkuat dengan Putusan Mahkamah Konstitusi Nomor 2-3/PUUV/2007 tanggal 30 Oktober 2007.

Penjatuhan pidana mati memunculkan kontroversi yang beragam. Mendasarkan pada konsep HAM bahwa hak hidup adalah hak yang bersifat nonderogabh rights. Instrumen internasional mendukung keberadaan hak hidup yang tercantum dalam Deklarasi HAM (Declaration of Human Rights) dan ICCPR. Demikian pula Pasal 28 A UUD 1945 yang menegaskan setiap orang berhak untuk hidup, serta berhak mempertahankan hidup dan kehidupannya. Pasal 28 I menyatakan hak untuk hidup merupakan hak asasi yang tidak dapat dikurangi dalam keadaan apapun. Dalam Pasal 28 I mengharuskan orang untuk memperhatikan hak hidup. Namun dalam Pasal $28 \mathrm{~J}$ menyebutkan setiap orang wajib menghormati hak asasi orang lain dan wajib tunduk pada pembatasan yang ditetapkan boleh Undang-Undang untuk menjamin pengakuan serta penghormatan hak dan kebebasan orang lain. Dalam pasal tersebut terdapat pertanggung jawaban bagi yang melanggar HAM, dan sistem hukum pidana Indonesia masih menerapkan pidana mati. Pertimbangan hakim dalam putusan pidana mati pada dasarnya untuk membela hak asasi manusia pada korban yang dirampas oleh terpidana. Pesan yang ingin disampaikan adalah setiap orang tidak dapat mencabut nyawa orang lain dan harus saling menghormati hak asasi sesama. Hal ini mengacu pada Pasal 28 J UUD 1945, dimana setiap orang wajib menghormati hak asasi manusia orang lain dan wajib tunduk pada pembatasan yang ditetapkan oleh Undang-Undang.

Kontroversi penerapan pidana mati yang berupa penolakan diantaranya disampaikan oleh Komisi Nasional Hak Asasi Manusia, Lembaga Perlindungan Saksi dan Korban, dan Kontras. Pandangan tersebut karena alasan kemanusiaan, dimana hak hidup adalah hak yang tidak dapat dikurangi dalam keadaan apapun. Hal ini disebutkan dalam Pasal 6 ayat (1) ICCPR, Pasal 28 A, dan Pasal 281 UUD 1945. Di samping itu hukum pidana Indonesia masih bersifat diskriminatif, dimana banyak ditemukan kesalahan dalam praktek peradilan pidana Indonesia. Beberapa kasus salah tangkap yang terjadi dalam praktek pengadilan antara lain: (1) kasus pembunuhan 
dengan terpidana Sengkon dan Karta, terpidana terbukti bersalah melakukan pembunuhan di pengadilan, namun saat di penjara bertemu dengan pembunuh aslinya; (2) kasus pembunuhan dengan terpidana Rusman Lakoro dan Rostin Mahaji, terpidana dipaksa mengaku membunuh anaknya Alta Lakoro, namun korban muncul kembali ke kampung halamannya dalam keadaah masih hidup, korban hanya melarikan diri; (3) kasus pembunuhan dengan terpidana Imam Hambali alias Kemat dan David Eko Priyanto, terpidana dipidana 17 dan 12 tahun penjara karena divonis sebagai pembunuh Asrori, ternyata pelakunya adalah Ryan. (www.mimbar-opini.com); (4) kasus pembunuhan dengan terpidana Budi Harjono, terpidana dijatuhi pidana karena membunuh ayahnya. Setelah 4 tahun dipenjara, seorang lakilaki bernama Marsin mengaku sebagai pelaku sesungguhnya. (www.indosiar.com).

Kalangan yang menolak pidana mati menganggap, pidana mati sama dengan negara memperpanjang rantai kekerasan dan bersifat pembalasan, sehingga penerapannya merupakan suatu kemunduran. Dalam pemikiran mereka hukuman mati tidak dapat menyelesaikan masalah kejahatan yangmeningkat spring dengan perkembangan peradaban manusia. Jika terpidana mati telah dieksekusi kemudian ditemukan novum bahwa pelaku sebenarnya bukan terpidana yang telah dieksekusi, maka tidak dapat diperbaiki kembali. Efek jera yang sangat diharapkan tidak termanifestasi dengan menjatuhkan hukuman mati. Kejahatan akan turun jika setiap kejahatan yang dilakukan oleh seseorang dipastikan aparat penegak hukum memproses sesuai dengan peraturan yang ada. Dengan demikian orang akan tercegah karena adanya kepastian proses yang transparan sesuai dengan peraturan. Hak Asasi Manusia merupakan hak yang berhubungan dengan hakekat keberadaan manusia. Penjatuhan pidana terhadap terpidana pelaku kejahatan harus berorientasi pada perlindungan HAM.

Model pemidanaan ini merupakan model pemidanaan yang humanistis atau pemidanaan yang berorientasi pada individualisasi pidana, dengan ciriciri sebagai berikut: (1) penerapan asas culpabilitas (tiada pidana tanpa kesalahan), (2) adanya flesibilitas atau elastisitas pemidanaan, (3) modifikasi (perubahan/penyesuaian) pemidanaan. Melalui model ini, hakim dapat 
menerapkan pidana yang dianggap cocok dengan keberadaan pelaku baik kejiwaan maupun kondisi fisiknya sehingga diharapkan adanya perubahan dari pelaku kearah yang lebih baik unfuk dapat kembali ke masyarakat (resosialisasi),

Implementasi hal tersebut tercermin dalam Rancangan KUHP Indonesia mengenai pidana mati atau perampasan hak hidup, yaitu: (1) pidana mati tidak dimasukkan sebagai pidana pokok, tetapi merupakan pidana yang bersifat khusus, dan pelaksanaannya bersifat melindungi masyarakat (defense social); (2) penjatuhan pidana mati tidak boleh dilakukan terhadap anak dibawah usia 18 tahun; (3) pelaksanaan pidana mati bagi wanita hamil ditunda sampai dengan wanita tersebut melahirkan; dan (4) pidana mati dilaksanakan setelah ada persetujuan atau penolakan grasi oleh presiden. Kebijakan formulasi penerapan pidana mati dalam Konsep Rancangan KUHP tersebut menuju pada kecenderungan penghapusan keberadaan pidana mati dari mulai pembatasan, pengurangan sampai dengan penghapusan pidana mati. Kecenderungan ini sesuai dengan penerapan pidana mati yang tercermin dalam praktek negara-negara lain di dunia, mengarah pada tren menghapuskan pidana mati.

Pembatasan tersebut yaitu putusan pidana mati hanya dapat dijatuhkan pada: (a) kejahatan yang bersifat serius, (b) tidak bertentangan dengan ketentuan kejahatan genoside, dan (c) diputuskan oleh pengadilan yang berwenang. Namun bagi negara yang telah menghapuskan pidana mati tidak boleh menggunakan ketentuan tersebut sebagai dasar menerapkan pidana mati kembali, dan tidak boleh berkontribusi terhadap pelaksanaan pidana mati dengan jalan mengekstradisi terpidana ke negara yang menerapkan pidana mati.

3. Kriteria Penjatuhan Pidana Mati yang Tidak Bertentangan dengan Hak Asasi Manusia

Hukum pidana pada dasarnya merupakan sarana untuk menjamin terlindunginya dan tercapainya ketertiban sosial dalam masyarakat. Sedangkan di Indonesia sendiri tujuan dari hukum pidana itu diorientasikan pada aspek social welfare dan social defence, sebagaimana yang termaktub dalam tujuan negara yang terdapat dalam alinea keempat Undang-undang 
Dasar $1945 .^{13}$ Penjatuhan pidana merupakan bagian yang berperan dalam proses pengadilan pidana. Oleh karena itu pelaksanaannya harus mendasarkan pada perspektif humanistis dan tujuan pidana integratif serta aliran pemidanaan modern yang mengutamakan perlindungan masyarakat. Perspektif humanistis menekankan pada syarat penjatuhan pidana yang meliputi perbuatan pidana (criminal act/ actus reus) dan pertanggungjawaban pidana (criminal responsibility/ mens rea). Dalam hukum pidana biasa disebut hukum pidana yang menekankan pada perbuatan (strajbaar heid van hetfeit) dan hukum pidana yang menekankan pada orang (strafbaar heid van de person).

Ada 3 hal yang menjadi titik pembicaraan dalam hukum pidana yaitu tindak pidana (crimmal act), pertanggungjawaban pidana (criminal responsibility), dan pengenaan pidana (punishment). Penerapan pidana dalam perspektif humanistis harus berdasarkan pada kesalahan pelaku atau yang dikenal dengan asas culpabilitas. Asas ini menyatakan bahwa "Nulfa Poena Sine Culpa" yang artinya tiada pidana tanpa kesalahan dari pelaku. Kesalahan dimanifestasikan dalam sikap batin tindak pidana yang berupa dengan sengaja atau dengan kealpaan. Adanya penerapan dualistis dalam mengkaji unsur tindak pidana, maka tidak ada tempat bagi kedua bentuk sikap batin/mental tersebut menjadi bagian inti dari tindak pidana.

Hal ini menjadi tugas pengadilan sebagai garda terdepan penjatuhan pidana, agar dalam menjatuhkan pidana mati harus benar-benar dapat membuktikan ada atau tidaknya kesalahan terpidana melalui proses pengadilan yang adil dan pembuktian yang faktual berdasarkan undangundang. Tujuan pemidanaan integratif dalam menjatuhkan pidana terutama pidana mati, harus memperhatikan faktor-faktor yang menyangkut HAM terpidana, dan menjadikan pidana bersifat operasional dan fungsional. Oleh karena itu pendekatan multi dimensional untuk dapat melihat dampak pemidanaan individual maupun sosial. Penjatuhan pidana mati dapat dikalkulasi terhadap dampaknya bagi perlindungan masyarakat (defense social) dan bagi terpidana sendiri. Aliran modern pemidanaan menekankan

13 Ferawati, 2015, Kajian Hukum dan HAM Terhadap Penjatuhan Pidana Mati Bagi Terpidana Narkotika, Jurnal IImu Hukum, 4 (3), hlm. 139. 
pada doktrin determinisme dimana manusia dianggap tidak mempunyai kebebasan kehendak, tapi kehendak manusia dipengaruhi oleh watak dari pelaku dan motif dari lingkungan di luar pelaku. Sehingga manusia tidak dapat dipertanggungjawabkan dan menolak pembalasan berdasarkan kesalahan subyektif. Bentuk pertanggungjawaban berupa tindakan bersifat perlindungan masyarakat. Mendasarkan pada konsep tersebut di atas maka dalam menerapkan pidana mati terhadap pelaku kejahatan dengan mengedepankan kriteria tindak pidana yang dilakukan sebagai berikut: (1) melampaui batas kemanusiaan, (2) mencelakai dan mengancam banyak manusia, (3) merusak generasi bangsa, (4) merusak peradaban bangsa, (5) merusak tatanan di muka bumi, (6) merugikan serta menghancurkan perekonomian negara. Jenis tindak pidana ini meliputi: narkoba, terorisme, pembunuhan berencana, penganiayaan berakibat mati secara sadis dan kejam, dan korupsi.

Penjatuhan pidana mati harus tetap memperhatikan hal-hal sebagai berikut: (1) proses peradilan dilakukan dengan adil dan atas dasar pembuktian yang faktual, (2) kesalahan terpidana harus benar-benar dibuktikan di pengadilan, (3) pengadilan yang memproses merupakan pengadilan yang berwenang, (4) hukum yang digunakan harus hukum yang sah, (5) hukuman mati dijatuhkan secara selektif dan telah berkekuatan hukum tetap, (6) terpidana mati didampingi rohaniawan sejak putusan bersifat tetap hingga menjelang eksekusi, (7) permintaan terakhir terpidana mati harus dapat dipenuhi oleh negara, (8) eksekusi dilaksanakan setelah semua hak-hak terpidana mati terpenuhi, (9) eksekusi dilaksanakan seeklusif mungkin dan tanpa menimbulkan penderitaan terpidana, (10) jenazah diperlakukan sebagaimana layaknya manusia tanpa mengadakan pembedaan.

\section{KESIMPULAN}

Mendasari uraian pembahasan dapat disimpulkan sebagai berikut: Pertama, Masalah hukuman mati, terdapat berbagai pandangan dari pemikiran para ahli hukum. Perspektif para aktifis hak asasi manusia (HAM) dianggap sebagai pelanggaran HAM, karena termasuk hukum yang kejam, melanggar hak hidup manusia, sebagaimana diatur dalam DUHAM PBB dan kovenan tentang hak-hak sipil dan politik. Kedua, Hukuman mati dalam pandangan HAM yang ada 
dalam UUD NRI 1945, dan UU Nomor 39 Tahun 1999 tentang HAM berusaha mengadopsi piagam HAM PBB untuk menghapuskan hukuman mati; tetapi masih tetap memperlakukan hukuman mati pada beberapa kasus kejahatan luar biasa (ordinary crime). Ketiga, dalam KUHP dan beberapa peraturan perundangundangan di Indonesia, ancaman pidana mati masih tetap dipertahankan, walaupun mendapat kritikan dari para aktifis HAM. Oleh karena itu, dalam Rancangan KUHP yang baru ada semacam kompromi (penal policy), dengan menjadikan hukuman mati bukan sebagai pidana pokok tetapi sebagai pidana altematif yang diperlakukan hanya bagi kejahatan luar biasa.

\section{DAFTAR PUSTAKA}

\section{Buku}

Supriyadi W., Eddyono dan Napitupuhi, Erasmus A.T., 2015. Hukuman Mati dalam R KUHP: Jalan Tengah Yang Meragukan, Institute for Criminal Justice Reform, Jakarta.

\section{Sumber Lain}

Anjari, Warih, 2015, Penjatuhan Pidana Mati di Indonesia dalam Perspektif Hak Asasi Manusia, Jurnal Widya Yustisia, 1 (2).

Asnawi, Habib Shulton, 2012, Hak Asasi Manusia Islam dan Barat: Studi Kritik Hukum Pidana Islam dan Hukuman Mati, Supremasi Hukum,1(1).

Astuti, Laras, 2016, Penegakan Hukum Pidana Indonesia dalam Penyelesaian Pelanggaran Hak Asasi Manusia, Jurnal Kosmik Hukum, 16 (2).

Daming, Saharuddin, 2016, Konfigurasi Pertarungan Abolisionisme Versus Retensionisme dalam Diskursus Keberadaan Lembaga Pidana Mati di Tingkat Global dan Nasional, Yustisi, 3 (1).

Eleanora, Fransiska Novita, 2012, Eksistensi Pidana Mati Dalam Perspektif Hukum Pidana, Widya, 29 (318).

Ferawati, 2015, Kajian Hukum dan Ham Terhadap Penjatuhan Pidana Mati Bagi Terpidana Narkotika, Jurnal Ilmu Hukum, 4 (3).

Haling, Syamsul, et.all,. 2018., Perlindungan Hak Asasi Anak Jalanan dalam Bidang Pendidikan Menurut Hukum Nasional dan Konvensi Internasional, Jurnal Hukum \& Pembangunan, 48 (2).

Huda, Chairul, 2011, Pola Pemberatan Pidana dalam Hukum Pidana Khusus, Jurnal Hukum, 18 (4). 
Kholiq, M. Abdul, 2007, Kontroversi Hukuman Mati Dan Kebijakan Regulasinya dalam RUU KUHP (Studi Komparatif Menurut Hukum Islam), Jurnal Hukum, $14(2)$.

Kolopita, Satrio Putra, 2013, Penegakan Hukum Atas Pidana Mati Terhadap Pelaku Tindak Pidana Narkotika, Lex Crimen, 4 (2).

Sumanto, Atet, 2004, Kontradiksi Hukuman Mati di Indonesia Dipandang dari Aspek Hak Asasi Manusia. Agama dan Para Ahli Hukum, Perspektif, 9(3).

Zulfa, Eva Achjani, 2007, Menakar Kembali Keberadaan Pidana Mati (Suatu Pergeseran Paradigma Pemidanaan Di Indonesia), Lex Jurnalica, 4 (2). 